\title{
Epidemiologic and clinical characteristics and outcomes of scorpion sting in the southeastern region of Turkey
}

\author{
Fevzi Yılmaz, M.D., ${ }^{1}$ Engin Deniz Arslan, M.D., ${ }^{1}$ Ali Demir, M.D., ${ }^{1}$ Cemil Kavalci, M.D., ${ }^{2}$ \\ Tamer Durdu, M.D., ${ }^{1}$ Muhittin Serkan Yılmaz, M.D., ${ }^{1}$ Cihat Yel, M.D., ${ }^{1}$ Sami Akbulut, M.D. ${ }^{3}$ \\ ${ }^{1}$ Department of Emergency Medicine, Numune Training and Research Hospital, Ankara \\ 2Department of Emergency Medicine, Baskent Universty Faculty of Medicine, Ankara \\ ${ }^{3}$ Department of General Surgery, Diyarbakir Training and Research Hospital, Diyarbakır
}

\begin{abstract}
BACKGROUND: Scorpion sting resulting in envenomation is a life-threatening emergency and causes serious health problems in tropical and subtropical regions. The aim of this study was to present the epidemiologic and clinical features of 123 cases presenting with symptoms of scorpion poisoning, a cause of preventable mortality and morbidity.
\end{abstract}

METHODS: This study retrospectively analyzed the epidemiologic and demographic features of a total of 123 patients who presented to Diyarbakır State Hospital Emergency Service with scorpion sting between January 2008 and December 2009.

RESULTS: Among 123 patients who presented to Diyarbakır State Hospital Emergency Service with scorpion sting between January 2008 and January $2009,62.6 \%(n=77)$ were female and $37.4 \%(n=46)$ were male. The mean age of the patients was $33.5 \pm 17.3$ years (2-80), and $27(22 \%)$ patients were younger than 18 years. The place of residence was rural region in $98(79.7 \%)$ patients and the city center in 25 (20.3\%). The majority of victims were stung by scorpions while they were at active work (42.3\%) or asleep (19.5\%) in bed. Eleven $(8.95 \%)$ patients were stung by a scorpion while putting on their own clothes.

CONCLUSION: This simple descriptive study will hopefully help healthcare providers take measures to prevent scorpion stings, which should take into consideration local epidemiological features.

Key words: Epidemiology, pain, scorpion sting.

\section{INTRODUCTION}

Scorpion sting (SS) cases are particularly common in the southeastern Anatolian region of Turkey due to geographical location, climate and the socioeconomic structure. ${ }^{[1,2]}$ There are 1500 subspecies of scorpions worldwide, with 50 subspecies having venom dangerous for humans. In South America, North Africa, and the Middle East, the Leiurus quinquestriatus, Androctonus crassicauda, and Buthus occitonus subspecies are dangerous. Turkey is estimated to host 13 scorpion

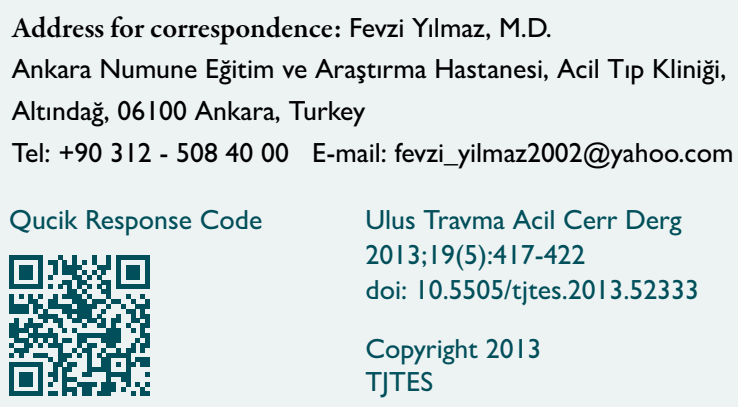

subspecies. SSs are relatively common in the eastern and southeastern Anatolian regions of our country, and the most common subspecies responsible for stings are the A. crassicauda and L. quinquestriatus species. ${ }^{[3]}$

Scorpion venom shows variability by subspecies and has a complex structure composed of neurotoxic proteins, salts, acidic proteins, and organic compounds, thereby having neurologic, cardiovascular, hematologic, and renal side effects, in addition to local effects such as redness, pain, burning, and swelling. ${ }^{[4]}$ Mortality due to SSs is associated with cardiac dysfunction and pulmonary edema. ${ }^{[5]}$ The clinical picture depends on the anatomical location of the sting and the victim's age, weight and health status. ${ }^{[2,6]}$ Although SSs are more common in adults and males, mortality is higher in children. ${ }^{[7,8]}$

Scorpion stings (SSs) in our country usually have a mild course. Approximately $94 \%$ of the incidents take place at night in homes in the countryside; $88 \%$ of cases do not require hospital admission. ${ }^{[1]}$ In SSs, mortality and morbidity can be remarkably decreased by timely anti-venom administration, adequate fluid resuscitation, cardiac monitoring, and 
renal function monitoring. ${ }^{[9]}$ In Turkey, Refik Saydam Hygiene Center (RSHC) manufactures the antivenom from A. crassicauda venom. This antivenom is in use for all SS cases. ${ }^{[0]}$

The aim of this study was to present the epidemiologic and clinical features of 123 cases presenting with symptoms of scorpion poisoning, a cause of preventable mortality and morbidity.

\section{MATERIALS AND METHODS}

This study retrospectively analyzed the epidemiologic and demographic features of a total of 123 patients who presented to Diyarbakır State Hospital Emergency Service with SS between January 2008 and January 2009. Age, sex, place of the incident, sting location on body, time to hospital admission, color of the scorpion, presenting complaint, systemic symptoms, treatment received, and seasonal admission rates were assessed. The clinical severity of each case was evaluated by Abroug's classification (Table I). ${ }^{\left[{ }^{[1]}\right.}$

The patients were monitored after history-taking and physical examination were completed. Depending on the severity of toxicity, all cases were given one or two $5 \mathrm{ml}$ scorpion polyvalent antivenom ampoules (Refik Saydam Hygiene Center, Turkey) on admission. In addition, tetanus toxoid was also administered when necessary.

Statistical analyses of the study data were performed with the help of the Statistical Package for the Social Sciences (SPSS) v. 16.0 software package. Descriptive data were expressed as frequency and percentage. Intergroup differences were analyzed using chi-square or Fisher test, depending on the features of the data. A p value below 0.05 was considered statistically significant.

\section{RESULTS}

Among 123 patients who presented to Diyarbakır State Hospital Emergency Service with SS between January 2008 and January 2009, 62.6\% $(n=77)$ were female and $37.4 \%(n=46)$ were male. The mean age of the patients was $33.5 \pm 17.3$ years (range, 2-80), and 27 (22\%) patients were younger than 18 years. Statistical analysis showed a significant difference between genders in terms of SSs $(p<0.005)$. Patient distribution according to age and gender is given in Table 2 .

The place of residence was rural region in 98 (79.7\%) patients and the city center in 25 (20.3\%). There was a significant difference between SS incidents in terms of place of residence $(p<0.005)$. The patients admitted to the emergency service in a mean of $4.3 \pm 3.5(1-14)$ hours after the trauma. The majority of the victims were stung by scorpions while they were at active work $(42.3 \%)$ or asleep (19.5\%) in bed. Eleven $(8.95 \%)$ patients were stung by a scorpion while putting on their clothes. The circumstances under which other sting incidents took place are given in Table 3.
Table I. Abroug's classification

\begin{tabular}{ll}
\hline Grade & Signs and symptoms \\
\hline Grade I & $\begin{array}{l}\text { Pain and/or paresthesia at the scorpion sting site. } \\
\text { Grade II }\end{array}$ \\
$\begin{array}{l}\text { Fever, chills, excessive sweating, nausea-vomiting, } \\
\text { diarrhea, hypertension and priapism. }\end{array}$ \\
Grade III & $\begin{array}{l}\text { Cardiovascular, respiratory, and/or neurologic } \\
\text { symptoms. }\end{array}$ \\
\hline
\end{tabular}

Table 2. The distribution of the scorpion sting cases according to age and sex

\begin{tabular}{|c|c|c|c|c|c|c|}
\hline \multirow[t]{2}{*}{ Age (year) } & \multicolumn{2}{|c|}{ Female } & \multicolumn{2}{|c|}{ Male } & \multicolumn{2}{|c|}{ Total } \\
\hline & $n$ & $\%$ & $n$ & $\%$ & $\mathbf{n}$ & $\%$ \\
\hline $0-5$ & 2 & 1.6 & I & 0.8 & 3 & 2.4 \\
\hline $6-11$ & 5 & 4 & 4 & 3.3 & 9 & 7.3 \\
\hline $12-18$ & 9 & 7.3 & 6 & 4.9 & 15 & 12.2 \\
\hline $19-49$ & 48 & 39 & 27 & 22 & 75 & 61 \\
\hline $50-65$ & 7 & 5.7 & 5 & 4.1 & 12 & 9.8 \\
\hline$>65$ & 6 & 4.9 & 3 & 2.4 & 9 & 7.3 \\
\hline Total & 77 & 62.6 & 46 & 37.4 & 123 & 100 \\
\hline
\end{tabular}

Scene of the SS incident was the patient's own home in 85 $(69.1 \%)$ and outdoors in 38 (30.9\%). Sixty-six (53.7\%) patients were stung by a black scorpion and $38(30.9 \%)$ by a yellow scorpion, whereas the color of the scorpion could not be identified in 19 (15.4\%) patients. With respect to the time of the sting, $56.4 \%$ of the patients were stung from 08:00-17:00, 18.3\% between 17:00-24:00, and 25.3\% between 24:00-08:00. The majority $(76 \%)$ of SSs took place in the summer through-

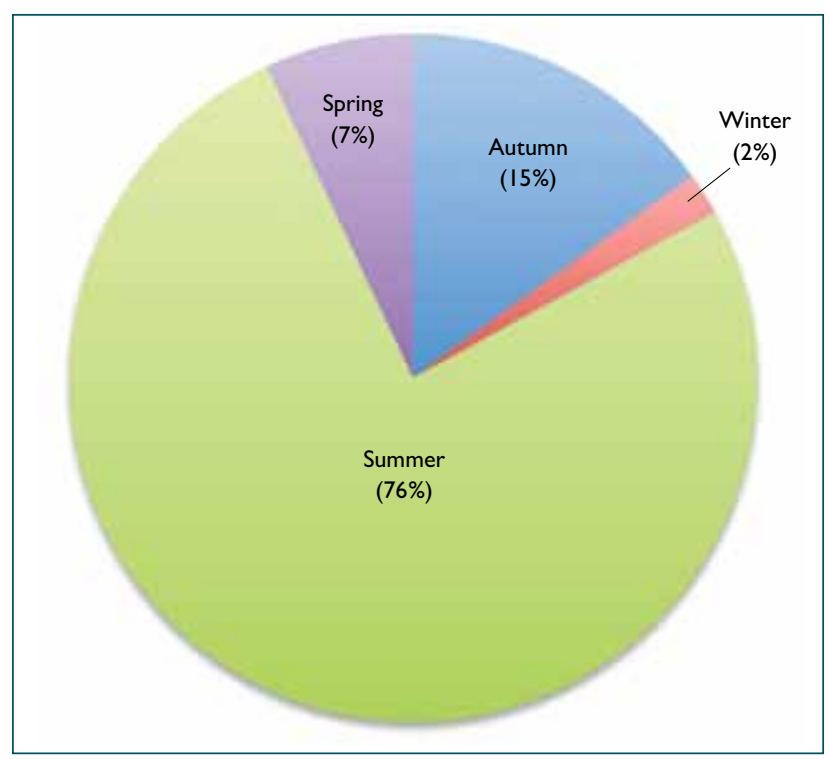

Figure 1. The seasonal distribution of the cases. 
Table 3. Demographic and epidemiological characteristics

\begin{tabular}{|c|c|c|}
\hline & $\mathbf{n}$ & $\%$ \\
\hline \multicolumn{3}{|l|}{ District } \\
\hline Urban & 25 & 20.3 \\
\hline Rural & 98 & 79.7 \\
\hline \multicolumn{3}{|l|}{ Color of scorpion } \\
\hline Black & 66 & 53.7 \\
\hline Yellow & 38 & 30.9 \\
\hline Unknown & 19 & 15.4 \\
\hline \multicolumn{3}{|c|}{$\begin{array}{l}\text { The activity being undertaken at the } \\
\text { time of the sting }\end{array}$} \\
\hline Putting on clothes & II & 8.9 \\
\hline Sleeping & 24 & 19.5 \\
\hline Working & 52 & 42.3 \\
\hline Eating a meal & 12 & 9.8 \\
\hline Sitting & 24 & 19.5 \\
\hline \multicolumn{3}{|l|}{ Site of scorpion sting } \\
\hline Head & 3 & 2.4 \\
\hline Neck & 2 & 1.6 \\
\hline Fingers & 76 & 61.8 \\
\hline Toes & 32 & 26.2 \\
\hline Ankle & 2 & 1.6 \\
\hline Leg & 4 & 3.2 \\
\hline Trunk & 3 & 2.4 \\
\hline Thigh & 1 & 0.8 \\
\hline \multicolumn{3}{|c|}{ Time to admission after scorpion sting } \\
\hline $0-1$ & 32 & 26 \\
\hline $\mathrm{I}-2$ & 56 & 45.5 \\
\hline $2-3$ & 22 & 17.9 \\
\hline $3-4$ & 9 & 7.3 \\
\hline$\geq 4$ & 4 & 3.3 \\
\hline \multicolumn{3}{|l|}{ Local signs } \\
\hline Local pain & 117 & 95.1 \\
\hline Hyperemia & 95 & 77.2 \\
\hline Swelling & 24 & 19.5 \\
\hline Itching & 23 & 18.7 \\
\hline Extremity tenderness & 57 & 46.3 \\
\hline Numbness & 8 & 6.5 \\
\hline
\end{tabular}

out Diyarbakır (Fig. I). SSs were located on the fingers in 76 (61.7\%) patients, toes in $32(26 \%)$ patients, and other parts of the body in 15 (12.3\%) patients (Table 3). There was a marked local pain in $117(95.1 \%)$ patients, redness in 95 (77.2\%), local edema in 24 (19.5\%), itching in 23 (18.7\%), numbness in the extremity in 8 (6.5\%), and tenderness in 57 (46.3\%). There were no significant differences between genders in terms of local edema, numbness in the extremity, local tenderness, and local pain ( $p>0.05$ for all symptoms), while fingers of females tended to be more commonly traumatized $(p=0.002)$ and they had more redness $(p=0.00 \mathrm{l})$. No patient developed cardiac dysfunction, myocardial damage, or death due to major systemic poisoning.

First aid or treatment was offered in all cases and included intravenous hydration, analgesia, antivenom therapy, and ice or cold pack. Antihistamines and steroids were used in nearly all patients ( $92 \%$ for both). No adverse reactions occurred against any of the drugs administered, including the antivenom.

\section{DISCUSSION}

Scorpions are distributed worldwide, but dangerous SSs more commonly take place in southwestern parts of the United States, Mexico, middle and northern regions of South America, India, and Middle Eastern countries. In our country, cases of SS are common in the south and southeastern Anatolian regions in the summer. Annually, nearly 100,000 SS cases are reported worldwide, 800 of which result in fatality. ${ }^{[2-14]}$

Scorpions live in jungles, deserts, and rocky areas; they become active at night and feed on insects and sometimes small rodents. ${ }^{[15]}$ They possess a wide range of colors, ranging from straw color to yellow, from light brown to black. ${ }^{[16]}$ Stings of L. quinquestriatus and A. crassicauda, also known as yellow and black scorpions, are encountered especially in countrysides in the summer and at nights. ${ }^{[13]}$

The clinical picture of SS poisoning depends on the subspecies, age, size, venom amount, and feeding characteristics of the scorpion as well as seasonal conditions. ${ }^{[14]}$ The scorpion venom is a water-soluble antigenic complex mixture of neurotoxin, cardiotoxin, nephrotoxin, hemolysins, phosphodiesterases, phospholipase, hyaluronidases, histamine, and other chemicals. ${ }^{[17]}$

Different scorpion subspecies may possess different venoms. Scorpion venom may also cause systemic effects in addition to local effects within the first 12-24 hours following the sting. Pain, heat, edema, and hematoma are commonly observed locally (Grade I). Systemically, hypotension or hypertension, respiratory failure, cardiovascular toxicity, hemolysis, renal failure, and hemorrhages at various sites may be observed. ${ }^{[18,19]}$ Severity of SS is considered to be indicated by neurological signs, which are observed in two-thirds of hospitalized patients. ${ }^{[14,20,21]}$ These manifestations vary greatly, from simple hyperthermia and muscarinics syndrome to severe neurological manifestations (coma and/or convulsions, myosis, mydriasis, anisocoria, nystagmus, squint, and erratic eye movements). ${ }^{[6]}$ In our study, pain, redness and extremity tenderness were signs and symptoms that were localized most commonly (Grade I). No patient developed systemic symptoms. 
A hospital-based study from the Kingdom of Saudi Arabia reported an age range of 2 months to $10 \mathrm{I}$ years in SS cases; $70.6 \%$ of the cases were under 20 years of age. ${ }^{[22]}$ In contrast, Nunes et al. ${ }^{[23]}$ from Brazil reported that most victims were equal to or older than 50 years. In our study, the majority of cases were between 19-49 years; 16,9\% were above 50 years of age, while $21.8 \%$ were children. We consider that this high incidence of stings among children originates from their higher inquisitive nature and risk-taking behavior, such that they lift up stones and put on their clothes and shoes without checking for scorpions.

Jahan et al. ${ }^{[24]}$ reported a male/female ratio of $1.9 / 1$, which was similar to $2.6 / 1$ reported by another study from Saudi Arabia. ${ }^{[22]}$ On the contrary, two studies from the United States and Australia reported that females were more commonly stung than males. ${ }^{[15,25]}$ In agreement with these results, our study had a female/male ratio of 1.6/I. Age range in SSs has shown variability in previous studies. In Qassim, Saudi Arabia, a lower mean age was reported (23.I \pm 16.8$).{ }^{[24]}$ Pardal et al. ${ }^{[26]}$ from Brazil reported a mean age of 33.6 18.3 for SS cases. Our results (mean age, $33.5 \pm 17.3$ years) were consistent with the latter study.

Jahan et al. ${ }^{[24]}$ reported that $49 \%$ of the SSs were caused by black scorpions, $38 \%$ by yellow scorpions, and the remaining (13\%) by other subspecies. In our study, $53.7 \%$ of SSs were by black scorpions and the rest $(30.9 \%)$ by yellow scorpions; no death occurred.

Clinical and experimental studies have reported that scorpion venom is distributed throughout the body very rapidly, and thus the time between SS and antivenom management is of critical importance. ${ }^{[27,28]}$ A delay in medical aid leads to an unfavorable prognosis; the risk is even higher in patients brought for medical care two hours after the sting. ${ }^{[2]}$ According to our data, 7I.5\% of SS cases were admitted to hospital and administered antivenom within two hours following the SS.

The majority of the previous studies have reported that SS cases are more prevalent in summer than winter, and this finding matches with the others in different studies. ${ }^{[22,29]}$ Morocco has a high incidence of SSs between June and September, Saudi Arabia between May and September, and Iran between April and October. ${ }^{[12,24,30]}$ SSs were most frequently reported in May and June in Texas. ${ }^{[31]}$ We also found that a majority (76\%) of stings took place during the summer (Fig. I). This result is consistent with previous studies investigating the seasonal variation of SSs in our country. ${ }^{[1,10,32-34]}$ In addition, people in Diyarbakır and nearby sleep on the roof and balcony or in the summer house because of the excessive heat between June and August, and the incidence of SS is higher in this group. Isbister et al., ${ }^{[35]}$ in a prospective study in Australia, reported that $71 \%$ of SSs occurred at night,
$86 \%$ occurred indoors, $15 \%$ occurred in bed, and 14\% occurred while the patients were dressing. In our study, the corresponding figures were $43.4 \%, 61.7 \%, 35.1 \%$, and $10 \%$, respectively.

Epidemiologic studies have reported that SSs are more common in the extremities. ${ }^{[6,10,30,33,36]}$ We also found that the $95.2 \%$ of stings took place in the extremities, including hands, arms, legs, thighs, and feet. Although SSs commonly involve the upper extremity in our country, literature data suggest a lower extremity predominance (58.6\%)..$^{[10,33,34,37]}$ In our study, stings most commonly involved the upper extremity (61.8\%). The reason for a higher incidence of stings that involve the extremities include people wearing sandals during hot seasons due to the low socioeconomic structure of Diyarbakır and the agriculture-based way of life in the rural area, agricultural laborers working in the fields unprotected, and children walking around with bare feet and carelessly lifting up stones and searching for scorpions at home with their bare hands. Stings to the head, neck, and other body parts typically take place during sleep or while putting clothes on.

In cases with SS, the level of consciousness, airway, respiration, and circulation should be checked. Vital signs should be monitored, and ECG and blood gas analysis should be carried out. External examination of the extremities should be performed, and peripheral pulses should be palpated. ${ }^{[38]}$ The region of the SS should be thoroughly washed with $\mathrm{NaHCO}_{3}$, $\mathrm{KMnO}_{4}$, or abundant water, and wound cleaning should be done at once. The patient and the involved extremity should be stabilized and intermittently bandaged to prevent the venom from spreading to the body. It may be beneficial to administer cold packs $\left(10-15^{\circ} \mathrm{C}\right)$ for $1-2$ hours, but cold injury should be avoided. Hypothermia prevents spreading of the venom and protects against an anaphylactic reaction; however, it should be begun in the first minutes of the sting. ${ }^{[38-40]}$ Some measures with no scientific background, such as sucking, application of henna or oil, or drinking milk are absolutely contraindicated. ${ }^{[12]}$

Treatment for SSs includes fluid and electrolyte replacement, antibiotics in some cases, tetanus toxoid, scorpion serum, analgesics to relieve pain, and calcium gluconate for muscle spasm. In cases with severe pulmonary edema, neurotoxicity, circulatory failure, and hematologic findings, oxygen, sublingual nifedipine, digoxin, furosemide, aminophylline, dopamine, vitamin $\mathrm{K}$, and fresh frozen plasma may be given, and phenobarbital and dexamethasone may be administered for 48 hours in cases with convulsions. ${ }^{[38,39,41]}$ Prazosin is reserved for cases with tachycardia, coldness and paleness in the extremities, hypertension, hypersalivation, and sweating. ${ }^{[42]}$

Antivenom therapy is still debated. Many authors consider it unnecessary, while others recommend it. ${ }^{[6,12,28,43,44]}$ In general, mild symptoms should be controlled with analgesics and 
antihistamines, whereas those with systemic signs should be administered antivenom after measures against an anaphylactic reaction have been taken ${ }^{[1,19]}$ In our study, antihistaminic drugs and steroids were applied in almost all patients (92\%).

In conclusion, conscientious medical care is of paramount importance in scorpion stings, which remain an important healthcare issue in our country. The results of this study have shown that scorpion stings were more common among females. Distal parts of the extremities were the most common site for scorpion stings. Scorpion stings in and around the Diyarbakır region do not appear to have severe or lifethreatening effects, and all patients were discharged home without sequelae. This simple descriptive study will hopefully help healthcare providers to take measures to prevent scorpion stings, which should take into consideration local epidemiological features. This information can also be utilized to identify population groups most in need of education on the prevention and treatment of scorpion stings.

\section{Conflict of interest: None declared.}

\section{REFERENCES}

1. Al B, Yllmaz D, Söğut Ö, Orak M, Üstündağ M, Bokurt S. Epidemiological, clinical characteristics and outcome of scorpion envenomation in Batman, Turkey: An Analysis of 12O Cases. JAEM 2009;8:3.

2. Tuuri RE, Reynolds S. Scorpion envenomation and antivenom therapy. Pediatr Emerg Care 2011;27:667-75.

3. Canpolat M, Per P, Gümüs H, Narin N, Kumandaş S. Convulsions as a rare complication of scorpion bite. Erciyes Medical Journal 2008;30:1759.

4. Ismail M, Abd-Elsalam MA, al-Ahaidib MS. Androctonus crassicauda (Olivier), a dangerous and unduly neglected scorpion-I. Pharmacological and clinical studies. Toxicon 1994;32:1599-618.

5. Razi E, Malekanrad E. Asymmetric pulmonary edema after scorpion sting: a case report. Rev Inst Med Trop Sao Paulo 2008;50:347-50.

6. de Roodt AR, García SI, Salomón OD, Segre L, Dolab JA, Funes RF, et al. Epidemiological and clinical aspects of scorpionism by Tityus trivittatus in Argentina. Toxicon 2003;41:971-7.

7. Celis A, Gaxiola-Robles R, Sevilla-Godínez E, Orozco Valerio Mde J, Armas J. Trends in mortality from scorpion stings in Mexico, 1979-2003. [Article in Spanish] Rev Panam Salud Publica 2007;21:373-80. [Abstract]

8. Gueron M, Ilia R, Sofer S. The cardiovascular system after scorpion envenomation. A review. J Toxicol Clin Toxicol 1992;30:245-58.

9. Akdur O, İkizceli İ, Avşaroğulları L, Özkan S, Sözüer EM. Akrep antiveni uygulamasına bağlı akut ürtiker: Olgu sunumu. Akademik Acil Tip Dergisi 2007;5:39-40.

10. Adiguzel S, Ozkan O, Inceoglu B. Epidemiological and clinical characteristics of scorpionism in children in Sanliurfa, Turkey. Toxicon 2007; 49:875-80.

11. Abroug F, Nouira S, Saguiga H. Envenomations scorpionniques: avences chimiques, physiopathologiques et therapeutiquis. Monograph 1994;168 .

12. Abourazzak S, Achour S, El Arqam L, Atmani S, Chaouki S, Semlali I. Epidemiological and clinical characteristics of scorpion stings in children in Fez, Morocco. J Venom Anim Toxins inci Trop Dis 2009;15:255-67.
13. Bawaskar HS, Bawaskar PH. Management of scorpion sting. Heart 1999;82:253-4

14. Gümüştekin M. Çevresel toksinler: Hayvan ısırma ve sokmaları. Türkiye Klinikleri. Farmakoloji Toksikoloji Özel Sayısı 2003;1:53-7.

15. Altıntaş K. Tibbi parazitoloji MN Medikal Nobel 2002;364-7.

16. Özcel MA, Daldal N. Parazitolojide arthropod hastalıkları ve vektörler. Türkiye Parazitoloji Derneği Yayını, No: 13, İzmir: 1997. s. 461-4.

17. Bawaskar HS, Bawaskar PH. Scorpion sting: update. J Assoc Physicians India 2012;60:46-55.

18. Kaya E, Çıkım K, Kuku İ, Şavlı H, Aydoğdu İ. Yılan ve akrep sokmalarında hastalarda görülen hematolojik bozukluklar ve klinik seyir. Turkish Journal of Heamatology 2002;19:161-2.

19. Özsu E, Saylan B, Tavlı V, Mese T, Sarıtas T. Akrep sokması sonrası gelisen geçici kardiyak sistolik disfonksiyon: olgu sunumu. Ege Pediatri Bülteni 2007;14:119-22.

20. Bahloul M, Ben Hamida C, Chtourou K, Ksibi H, Dammak H, Kallel $\mathrm{H}$, et al. Evidence of myocardial ischaemia in severe scorpion envenomation. Myocardial perfusion scintigraphy study. Intensive Care Med 2004;30:461-7.

21. Elatrous S, Nouira S, Besbes-Ouanes L, Boussarsar M, Boukef R, Marghli $\mathrm{S}$, et al. Dobutamine in severe scorpion envenomation: effects on standard hemodynamics, right ventricular performance, and tissue oxygenation. Chest 1999;116:748-53.

22. Al-Asmari AK, Al-Saif AA. Scorpion sting syndrome in a general hospital in Saudi Arabia. Saudi Med J 2004;25:64-70.

23. Nunes CS, Bevilacqua PD, Jardim CC. Demographic and spatial aspects of scorpion stings in the northwest region of Belo Horizonte City, Minas Gerais, 1993-1996. [Article in Portuguese] Cad Saude Publica 2000;16:213-23. [Abstract]

24. Jahan S, Mohammed Al Saigul A, Abdul Rahim Hamed S. Scorpion stings in Qassim, Saudi Arabia-a 5-year surveillance report. Toxicon 2007;50:302-5

25. Isbister GK, Volschenk ES, Balit CR, Harvey MS. Australian scorpion stings: a prospective study of definite stings. Toxicon 2003;41:877-83.

26. Pardal PP, Castro LC, Jennings E, Pardal JS, Monteiro MR. Epidemiological and clinical aspects of scorpion envenomation in the region of Santarém, Pará, Brazil. [Article in Portuguese] Rev Soc Bras Med Trop 2003;36:349-53. [Abstract]

27. Petricevich VL. Scorpion venom and the inflammatory response. Mediators Inflamm 2010;2010:903295.

28. Ghalim N, El-Hafny B, Sebti F, Heikel J, Lazar N, Moustanir R, et al. Scorpion envenomation and serotherapy in Morocco. Am J Trop Med Hyg 2000;62:277-83.

29. Bosnak M, Ece A, Yolbas I, Bosnak V, Kaplan M, Gurkan F. Scorpion sting envenomation in children in southeast Turkey. Wilderness Environ Med 2009;20:118-24.

30. Pipelzadeh MH, Jalali A, Taraz M, Pourabbas R, Zaremirakabadi A. An epidemiological and a clinical study on scorpionism by the Iranian scorpion Hemiscorpius lepturus. Toxicon 2007;50:984-92.

31. Forrester MB, Stanley SK. Epidemiology of scorpion envenomations in Texas. Vet Hum Toxicol 2004;46:219-21.

32. Uluğ M, Yaman Y, Yapici F, Can-Uluğ N. Scorpion envenomation in children: an analysis of 99 cases. Turk J Pediatr 2012;54:119-27.

33. Ozkan O, Adigüzel S, Yakiştiran S, Cesaretli Y, Orman M, Karaer KZ. Androctonus crassicauda (Olivier 1807) scorpionism in the Sanliurfa provinces of Turkey. Turkiye Parazitol Derg 2006;30:239-45.

34. Altınkaynak S, Ertekin V, Alp H. Scorpion envenomation in children. Turk Arch Pediatr 2002;37:48-54. 
35. Isbister GK, Volschenk ES, Balit CR, Harvey MS. Australian scorpion stings: a prospective study of definite stings. Toxicon 2003;41:877-83.

36. Jarrar BM, Al-Rowaily MA. Epidemiological aspects of scorpion stings in Al-Jouf Province, Saudi Arabia. Ann Saudi Med 2008;28:183-7.

37. Söker M, Haspolat K. Scorpion sting in children. Çocuk Sağlı̆̆1 Hastalıklar1 Derg 2000;43:43-51.

38. Kurtoğlu S. Zehirlenmeler, teşhis ve tedavi. Kayseri: Erciyes Üniversitesi Yayınları, 1992.

39. Söker M, Haspolat K. Güneydoğu ve Anadolu bölgesinde çocuklarda akrep sokması: 64 vakanın değerlendirilmesi. Çocuk Sağliğı ve Hastalıklar1 Dergisi 2000;43:43-50.
40. Santhanakrishnan BR, Gajalakshmi BS. Pathogenesis of cardiovascular complications in children following scorpion envenoming. Ann Trop Paediatr 1986;6:117-21.

41. el-Amin EO, Elidrissy A, Hamid HS, Sultan OM, Safar RA. Scorpion sting: a management problem. Ann Trop Paediatr 1991;11:143-8.

42. Koseoglu Z, Koseoglu A. Use of prazosin in the treatment of scorpion envenomation. Am J Ther 2006;13:285-7.

43. Bawaskar HS, Bawaskar PH. Clinical profile of severe scorpion envenomation in children at rural setting. Indian Pediatr 2003;40:1072-5.

44. Ismail M. Treatment of the scorpion envenoming syndrome: 12 -years experience with serotherapy. Int J Antimicrob Agents 2003;21:170-4.

\section{KLINIK ÇALIŞMA - ÖZET}

\section{Türkiye'nin Güneydoğu Anadolu Bölgesi'nde akrep sokmalarının epidemiyolojik, klinik özellikleri ve sonuçları \\ Dr. Fevzi Yılmaz, ${ }^{1}$ Dr. Engin Deniz Arslan, ${ }^{1}$ Dr. Ali Demir, ${ }^{1}$ Dr. Cemil Kavalci, ${ }^{2}$ Dr. Tamer Durdu, ${ }^{1}$ Dr. Muhittin Serkan Yılmaz, ${ }^{1}$ Dr. Cihat Yel, ${ }^{1}$ Dr. Sami Akbulut ${ }^{3}$}

1Ankara Numune Eğitim ve Araştırma Hastanesi, Acil Tıp Kliniği, Ankara
${ }^{2}$ Başkent Üniversitesi Tıp Fakültesi, Acil Tıp Anabilim Dalı, Ankara
${ }^{3}$ Diyarbakır Eğitim ve Araştırma Hastanesi, Genel Cerrahi Kliniği, Diyarbakır

AMAÇ: Zehirlenmelere neden olan akrep sokmaları yaşamı tehdit eden acil bir durumdur ve tropikal ve subtropikal bölgelerde ciddi sağlık sorunlarına neden olurlar. Bu çalışmanın amacı mortalite ve morbiditenin önlenebilir nedenlerinden olan akrep sokması nedeni ile başvuran I 23 hastanın epidemiyolojik ve klinik özelliklerini belirlemektir.

GEREÇ VE YÖNTEM: Bu çalışmada Ocak 2008 ile Eylül 2009 arasında Diyarbakır Devlet Hastanesi Acil Servis'ine akrep sokması nedeni ile başvuran 123 hastanın demografik ve epidemiyolojik özellikleri geriye dönük olarak incelendi.

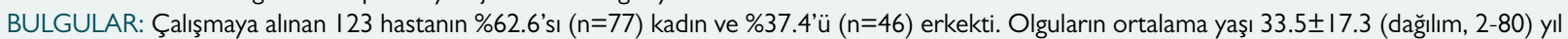
ve 27 (\%22) hasta 18 yaşından daha gençti. Hastaların 98'i (\%79.7) kırsal alandan, 25’i (\%20.3) şehir merkezindendi. Olguların çoğunluğu (\%42.3) aktif çalışma sırasında ve uykuda (\%।9.5) akrep sokmasına maruz kaldı. On bir (\%8.95) hasta da evde çamaşırlarını yerleştirirken akrep sokmasına maruz kalmıştı.

TARTIŞMA: Bu çalışmanın yöresel epidemiyolojik özellikleri göz önünde tutarak, sağlık çalışanlarına akrep sokmalarından korunma için gerekli önlemlerin alınmasında yardımcı olabileceğini umarız.

Key words: Ağrı, akrep sokması, epidemiyoloji.

Ulus Travma Acil Cerr Derg 2013;19(5):417-422 doi: 10.5505/tjtes.2013.52333 